\title{
Preparing the Next Generation of Institutional Leaders: Strategic Supports for Mid-Career Faculty
}

\author{
Vicki L. Baker and Caroline E. N. Manning
}

\begin{abstract}
Calls for leadership development and associated supports for faculty members are growing in prominence in higher education. Yet traditional leadership development efforts in higher education fail to account for both individual and institutional needs as critical to fostering a leadership pipeline with multiple entry points. This article offers succession management and onboarding as important and necessary steps to facilitating a more deliberate, strategic approach to supporting the next generation of institutional leaders-mid-career faculty members.
\end{abstract}

Keywords: mid-career faculty, leadership development, succession management, onboarding

"I have unfortunately never had any formal [leadership] training-it has all been 'on the job.'"

"II need support on] being more aware of the role I am in or should be in during a particular situation, i.e., managing, leading, mentoring, coaching."

The first quotation above is from a mid-career faculty member who participated in a longitudinal study of associate professors in the Great Lakes Colleges Association (GLCA) (Baker et al., 2017). The second 
quotation is from a mid-career faculty member in a formal leadership position at a research university who attended a one-day workshop facilitated by the lead author titled "Developing Yourself and Others Through Coaching." Together, these experiences underscore the challenges associated with the mid-career stage: lack of leadership development opportunities, ambiguity of job responsibilities once in leadership roles, and lack of preparation to perform responsibilities associated with the new role.

Scholars have drawn attention to the importance of leadership and leadership development in higher education, noting that current conceptions of leadership supports are insufficient due to the increasing complexity that characterizes the academy (Amey, 2006; Baker et al., 2019; Mathews, 2018; Templeton \& O'Meara, 2018). In his article published in Change, Mathews (2018) urged the academy to cultivate its own leaders. At present, the majority of mid-level positions such as department chairs, associate deans, and program directors in higher education are filled with in-house faculty. This reality thus requires investments in sustained leadership development as supported through delivery of internal training programs that develop aspiring institutional leaders. The question becomes, what types of supports can meet this call? One possibility is institutional support in the form of succession management and onboarding. The aim of this article is thus to discuss the merits of implementing these traditionally private industry supports in the context of higher education in order to fit the needs of mid-career faculty.

Succession management coupled with onboarding programming for mid-career faculty are necessary career development tools that can create a more strategic, defined leadership pipeline in the academy (Baker et al., 2019) that supports outcomes at the institutional and individual levels. Succession management is a systematic effort aimed at ensuring continuity in key positions that span multiple organizational levels (Rothwell et al., 2015). A focus on succession management supports our overall goal of taking a holistic organizational view of talent management aimed at providing the necessary support 
and development for all current and future leadership positions, rather than just for a single position. Onboarding, a component of a systematic succession management effort, is defined as the "acquiring, accommodating, assimilating, and accelerating of new leaders into the organizational culture and business" (Ndunguru, 2012, p. 6) and is a process whereby organizational members are socialized as part of a longer-term career development approach. Researchers have revealed positive connections among succession management, onboarding, and employee productivity and satisfaction in industry (Bradt \& Vonnegut, 2009; Rothwell et al., 2015). These career development tools thus have the potential to have similar effects in higher education.

\section{What We Know About Mid-Career}

For decades, scholars and practitioners have studied and sought to support mid-career faculty members (Baker \& Manning, in press). Emerging from this research is the overarching message that midcareer faculty development ought to be viewed as a strategic means toward achieving prosperous outcomes at both the institutional and individual levels (Baker et al., 2017; Baker \& Manning, in press), which thus accentuates the need for increased career-stage specific developmental support. Scholars have revealed that the mid-career stage is plagued with growing service expectations (Misra et al., 2011) as well as misalignment between workload and reward systems, including vague and unclear criteria for advancement to full professorship (Baker \& Manning, in press). Exacerbating this issue is the insufficient (or nonexistent) career development support available to faculty members post achievement of tenure and promotion (Strage \& Merdinger, 2015). The result is that many mid-career faculty members feel stalled yet find themselves in critical formal and informal leadership roles at the institutions at which they are employed (Baker \& Manning, in press). Women and other underrepresented groups are even more disadvantaged at this career stage due to antiquated and, in some 
cases, biased institutional policies and structures (Croom, 2017; Eddy \& Ward, 2015; Hart, 2016).

Despite increased calls for more leadership development among the faculty ranks (Austin \& Sorcinelli, 2013; June, 2017a, 2017b; Norman, 2019), the response permeating the academy is clear-leadership roles are viewed negatively and should be avoided if possible due to the sometimes negative career implications associated with assuming such roles. Specifically, scholars have revealed that taking on leadership roles at mid-career delays and, in some cases, derails the successful achievement of full professorship (Baker et al., 2018; Ward \& WolfWendel, 2012). Furthermore, the mid-career faculty members who do assume leadership positions are underprepared for their new roles.

Prior research conducted by the first author and her colleagues examined the leadership pipeline among a consortium of liberal arts colleges (Baker et al., 2019). Research findings revealed that the leadership point of entry was the department chair position, but that position also appeared to be the penultimate aspiration for most associate professors given the lack of leadership development support provided to be successful in this role. Findings further revealed that many faculty members were advised to avoid leadership commitments given leadership roles are not accounted for nor do they serve to help with advancement to full professorship (Baker et al., 2019). While this may be sound advice given the current realities of the academy, the larger message is an unfortunate one. The very people who have the greatest promise for serving in these roles are both discouraged from pursuing them and ill-informed about what such roles would entail.

\section{What Are Mid-Career Faculty Members Saying?}

In the lead author's prior research, 35\% of mid-career faculty members said they received no formal training on their respective campuses to support success in formal leadership positions (e.g., department chair, committee chair, faculty representative; Baker et al., 2017; Lunsford 
et al., 2018). Of those same faculty members, $25 \%$ noted that they sought outside training and support mostly through professional or disciplinary associations. Only for some did their institutions provide financial support to seek this training. Twenty percent of faculty respondents described seeking the support of others in similar roles, considered to be exemplars, and also "learning on the job" through trial and error, resulting in missteps and a very steep learning curve.

At the individual level, it is clear that mid-career faculty are in need of greater career development support (e.g., programming and financial resources) and are eager to seek professional development opportunities as long as they are the "right" opportunities (e.g., specific to career stage and position needs; Baker \& Manning, in press; Baker et al., 2018). However, failure to develop and hone leadership skills when first introduced to leadership opportunities, such as when a mid-career faculty member assumes the department or committee chair role, often results in disinterest in future leadership opportunities. The department chair position, for example, is an opportunity for initial leadership within the institution, but the necessary skill and leadership development that ought to prepare faculty for this position are wanting, thus leaving little desire to assume this leadership role (Baker et al., 2019; Baker \& Manning, in press). Colleges and universities are missing an opportunity to identify and grow top talent early in the leadership pipeline due to this lack of intentional development through succession management.

Institutionally speaking, leaders across colleges and universities need to be more strategic about the ways in which leadership roles are defined, conceived, and supported financially on their campuses. Women and faculty of color, in particular, are at a disadvantage in the leadership pipeline given the political undertones of leadership and promotion decisions, such as stricter requirements for women and faculty of color and unclear expectations on the pathway to leadership paved with conflicting messages. This, in turn, contributes to a lack of interest in seeking either leadership positions or full professorship (Croom, 2017; Hart, 2016; Ward \& Wolf-Wendel, 2012, 2016). 
Therefore, a deliberate and strategic approach to developing the next generation of leaders is needed in the academy.

The implications of poorly developed leaders extend beyond the underprepared individual tasked with such responsibilities. Think about the professional (and personal) experiences of departmental faculty members led by a poorly prepared department chair, or the committee members managed by an ill-equipped committee chairperson. Frustration, wasted time, lack of direction, and disengagement are the likely result. Not to mention, this is just among the faculty members. What about the implications for staff members and campus administrators? While we, as members of the academy, find it unfortunate to lose an amazing colleague, we should be deeply concerned about the disengaged and or poorly prepared faculty member who stays and is tasked with "leading us." In stark contrast, when department chairs are supported, for example, they can provide much needed reinforcement and guidance to other mid-career faculty members and cultivate effective means of communication among colleagues, given that department chairs realize the challenges and responsibilities that come with the mid-career stage (Creswell \& Brown, 1992; DeZure et al., 2014; Laursen \& Rocque, 2009).

For years, institutional leaders have touted their success in preparing the next generation of leaders, our students, to not only cope with an ever-changing world but also help create one in which we can all be proud. However, how can we be sure such development is occurring at the student level when institutional leaders, faculty developers, and others tasked with faculty development responsibilities are inadequately investing in leadership development at the faculty level? While we don't believe all industry practices are appropriate or useful in higher education, succession management and onboarding are two career development tools that can add value to the career development of mid-career faculty members and the institutions in which they are employed. Before we discuss the merits of implementing corporate strategies in the context of higher education, we first address the reported experiences of mid-career faculty members that inform the institutional strategies proposed in this article. 


\section{Mid-Career Shifts: Institutional and Individual Effects}

Congrats-you have tenure ... Now what? Although quite an accomplishment resulting from years of hard work and dedication to teaching and scholarship, tenure and promotion is the gateway to the mid-career faculty stage, a career stage characterized by nebulous job structure and limited career direction (Petter et al., 2018). This new career stage has its own set of challenges, as these more seasoned faculty members navigate their professional lives but often without the same zeal that they brought to their career as a new hire years earlier. This stage surfaces not only the challenges faced as individuals but also the resulting consequences for the institution as a whole if structures are not implemented to best support these evolving faculty.

\section{Individual}

The mid-career faculty stage is plagued by feelings of stagnation and lack of career direction (Baker \& Manning, in press; Baldwin, 1981). When tenured faculty are no longer at the receiving end of the galvanizing developmental support that they once received early in their careers, they become vulnerable to plateauing professionally (Baker \& Manning, in press; Clark \& Corcoran, 1989). At the root of the lack of support directed toward mid-career faculty members is the misconception "that since [they have] reached the milestone of tenure and/ or promotion that 'they have it figured out'" (Petter et al., 2018, p. 565). This misconception, in turn, propels the cyclic impasse of limited resources and support, such as mentoring, directed toward the midcareer faculty member to help combat the stresses resulting from the career stage (Austin \& Sorcinelli, 2013).

Scholarly work over the past several decades has served to voice some of the specific concerns raised by mid-career faculty as they navigate their academic careers (Baker \& Manning, in press). Midcareer faculty particularly report feelings of tension and stress as they shoulder increased burdens of responsibility beyond the teaching and 
research that was expected prior to tenure. Faculty are now expected to assume more leadership roles (Austin, 2010; Baker-Fletcher et al., 2005) while still producing research output and maintaining favorable teaching ratings. However, despite these increased demands, research is what aids mid-career associate professors to reach full professorship, a goal of many faculty at this stage, thus contributing to the tension felt by these faculty members (Welch et al., 2019).

Another source of stress for mid-career faculty is the feeling of isolation that characterizes this stage (Lamber et al., 1993; Olsen, 1992). There are a number of detrimental consequences of the isolation experienced, such as stymied morale, creativity, and vitality and limited intellectual stimulation because of a lack of collaboration with colleagues specializing in the same field (Lamber et al., 1993). Although very disadvantageous for the well-being of faculty members, the consequential effects of these challenges do not just start and end with the faculty member as an individual but rather also take their toll on institutions. At their core, these challenges link to leadership aspiration and preparation shortcomings; institutional leaders and their mid-career faculty members need to foster a more strategic leadership pipeline.

\section{Institution}

Reiterating mid-career developmental support as a valuable investment, Romano et al. (2004) aptly stated that mid-career faculty members have many years left to contribute to the institution, and they are more suited to serve the institution when feeling engaged and connected to the resources and faculty around them. That the mid-career stage is characterized by stagnation and waning vitality is a disservice to the institution, which benefits from productive faculty (Baker \& Manning, in press).

Furthermore, as previously mentioned, mid-career faculty suffer from increased loneliness in their careers. According to Olsen (1992), feelings of loneliness and lack of support are major reasons why faculty leave their positions. This reality reinforces the importance of succession management and onboarding programming whereby leadership 
development is initiated and implemented during that first year after tenure, given it fosters community among faculty from different disciplines. Belker (1985), and later DeZure et al. (2014), pointed to the stakeholder role institutional administrators ought to play in investing in the development of faculty at the mid-career stage, as vital faculty are better able to contribute to the growth of the institution "at the programmatic, departmental, and community levels" (Baker \& Manning, in press). Previous scholarly work has astutely pointed out that given that mid-career stagnation is more often a function of the career stage itself rather than the individual, it is critical to look to the environment to mitigate the feelings of stagnation that occurs during this stage (Furniss, 1981).

A likely contributing factor to feelings of stagnation in mid-career faculty is shrinking institutional budgets, which are even more challenged from the COVID-19 pandemic, thus forcing institutional leaders to engage in a re-evaluation of internal institutional investments and funding priorities. While faculty development funds, for example, are not likely to be used in the same ways they were prior to the pandemic, they can still be used to help faculty members develop the skills needed to support their students, departmental colleagues, and institutional mission. For example, travel funds can now be reallocated to support mid-career faculty participation in online training and webinars aimed at developing skills to foster team cohesion or career development of departmental members. The bottom line is that now is not the time to shrink or eliminate faculty development budgets but to instead re-envision how such funds are used and how such an investment in faculty can serve the institution and mid-career faculty growth and development during times of crisis. Institutional culture and climate contribute to faculty vitality, thus reiterating that institutional leaders ought to play a role in financially supporting faculty development programming to prevent mid-career faculty from succumbing to feeling stuck (Strage et al., 2008).

With this prior research in mind, we turn to faculty members' working environments, the institution, as a means of providing professionally 
relevant resources. In the following section, we offer insight into succession management and onboarding support programs and their importance for an overall talent management strategy.

\section{Cultivating the Leadership Pipeline}

In 2008, leaders of the Society for Human Resource Management (SHRM) offered an astute observation about the implications of the recession, such as changing workforce demographics, global competition, and advances in information technology, as factors that prompted organizational leaders to examine and re-evaluate how they lead and operate (Mirza, 2009). Those same environmental forces also affected higher education in much of the same ways across areas, including student (and faculty) recruitment and retention, initiatives related to diversity and inclusion, projections of return on investment, and evidence of student learning outcomes. Around the globe, we are once again faced with workforce and organizational mission challenges due to the global COVID-19 pandemic, which is requiring a new leadership model, one that is adaptive and anticipatory, rather than reactive, to internal and external forces of change (Day, 2007). Perhaps now more than ever, higher education institutions need to be more deliberate and strategic about their leadership development strategy. Such internal investments could, and should, include succession management and onboarding.

\section{Succession Management}

Succession management is a systematic career development tool that focuses on critical organizational roles and the identification and assessment of high potential individuals who can serve as successors, and it provides those identified individuals with the appropriate skills and experience for present and future leadership positions and roles (Rothwell et al., 2015). The benefits of succession management are evident given the role such processes play in individual career advancement 
and skill development (Rothwell et al., 2015). Succession management also facilitates the attainment of organizational-level outcomes such as the achievement of key performance metrics (Groves, 2019) and longterm sustainability (Chiocchio \& Gharibpour, 2017).

The primary goal of succession management is to ensure that an organization has a continuous supply of top talent from which to draw. This is accomplished through a five-step process: (1) determining demands for leadership roles, (2) assessing the supply of current leadership as well as the pipeline of future leaders in the organization, (3) identifying gaps in the organization where critical leadership skills are needed as well as future leadership needs in an effort to anticipate organizational needs, (4) fostering a training and development portfolio that enables critical skill development and knowledge transfer to current and emerging leaders, and (5) assessing leaders' progress and achievement of identified key performance and organizational measures of success (Dye et al., 2016).

Succession management is particularly salient for higher education to answer calls to cultivate our own (Mathews, 2018) and address the lack of mid-career stage development supports noted in prior research and practice (Baker \& Manning, in press). Administrators highlight midcareer faculty development as a priority (Baker et al., 2015) yet lack a clear direction of how and what to focus on. Furthermore, the leadership pipeline is stifled in higher education, and the mid-career stage presents an opportunity to be more strategic and deliberate about what such development can (and should) entail (Baker et al., 2019). In the current article, we outline a succession management framework that invests in long-term planning and talent management, aimed at long-term growth and thriving within the organization at institutional and individual levels.

\section{Onboarding}

The term onboarding has been around since the 1990s but has become more prevalent over the past 15 years given the practice is considered 
a long-term, strategic approach to integrating new hires or recently appointed individuals into the organization and associated culture. The goal of onboarding is to ensure the newly appointed individual gains access to the needed information, tools, and materials to perform their job successfully (Ndunguru, 2012). Onboarding, contrary to orientation, is an ongoing process aimed at helping an employee become established in the organization, whereas orientation is a one-time event.

Given the process to recruit, interview, and train organizational newcomers is costly, onboarding must be tailored to meet the needs of the employee and organization. When done effectively, onboarding can expedite the time in which the employee can begin to contribute to the organization in the new role; increase employee performance and productivity; support the development of strong interpersonal relationships; contribute to increased job satisfaction and organizational loyalty; and enhance employee engagement and retention (Nguyen, 2018; Snell, 2006). Onboarding can also serve to connect organizational roles to organizational outcomes in order to foster individual growth and promote achievement of organizational aims (Hirsch, 2017). Hirsch (2017) also found that employees are more likely to stay at an organization if they have a good onboarding experience, and organizations benefit from greater new hire productivity as a result, thus serving as a strong return on investment.

Similar to succession management, onboarding involves a five-step process that spans assessment, design, organization, implementation, and evaluation (Maurer, 2016). First, assessment efforts inform content development, promote inclusion, and facilitate understanding about current and future needs. The assessment step informs Step 2, design, by guiding decision-making about the structure of the onboarding efforts, including goals for the onboarding effort and a clear understanding of training and delivery methods (e.g., classroom, online learning, mentoring). Next, organization (Step 3) focuses on the flow and scaffolding of a given onboarding effort. Decisions are focused on introduction, current and needed audience understanding, in-program knowledge assessment checks, and program debrief and wrap 
up. Lastly, implementation (Step 4) and evaluation (Step 5) involve running the full program and evaluating the achievement of outcomes at the individual and organizational levels.

In stark contrast to the comprehensive five-step process, the "sink or swim" approach to leadership development that permeates the academy is problematic for retention (Rockquemore, \& Ann, 2016) and further exacerbates the lack of well-prepared institutional leaders. Effective succession management and onboarding efforts support the development of well-prepared mid-career faculty members who are the "bridge between faculty generations by mentoring new colleagues and assuming leadership duties as their senior colleagues move toward retirement" (Baldwin \& Chang, 2006, p. 28). This notion of a bridge is apropos given the need for processes and people to make connections across the many institutional layers and stakeholders present. The sink or swim approach that permeates the academy yields frustrated faculty members, thus we argue that an effective onboarding program, as part of a comprehensive, systematic succession management effort, will support achievement of individual and institutional outcomes. Perhaps the most important outcome will be a more strategic and defined leadership pipeline that creates career development opportunities for midcareer faculty members and that ensures effective leaders are tasked with advancing institutional vision and mission.

\section{What Colleges and Universities Need to Do}

Who should take the lead on succession management and onboarding efforts? In the domain of higher education, faculty development is typically a shared responsibility among a variety of individuals and committees, including, but not limited to, the chief academic officer, dean or associate dean of faculty, department chairs, directors of centers for teaching and learning, faculty development committees, and personnel committees. Therefore, succession management and onboarding efforts must be supported across the academy. A benefit 
to this collaborative approach is the opportunity to encounter a range of views and perspectives of individuals involved in the process, given the different touch points a mid-career faculty member has with each. A drawback is the possibility of no clear understanding of who has primary responsibility for the overall delivery and evaluation of the effectiveness of succession management and onboarding efforts. Furthermore, the nature of faculty work and the tenure system differs from industry, thus resulting in more diversified career paths along the leadership pipeline for mid-career faculty. However, the basic tenets and goals of succession management and onboarding are applicable in higher education and thus have the potential to provide faculty with career development tools.

\section{Recommendations for Developing and Incorporating Succession Management and Onboarding in Higher Education}

A basic tenet of effective succession management and onboarding is a clear line of sight demonstrating how an employee's work contributes to overall organizational success (Korn Ferry International, 2018). Taking a cue from industry, the answers related to the following four points will serve as the foundation of and inform the development of an effective succession management program for mid-career faculty in higher education:

1. understanding of key leadership positions on campus along the leadership pipeline;

2. transparency about the competencies needed to be successful in the various leadership roles;

3. clarity about the connection between leadership positions (individual success) and institutional success along with explicit performance metrics; and

4. clearly defined and consistent mechanisms by which needed leadership competencies are clearly and regularly communicated (and revised as needed). 
Based on prior research and practice to date (Baker et al., 2019; Baker \& Manning, in press), the consistency with which these four building blocks are present, evaluated with regularity, and assessed is limited. In the following section, we outline critical steps that provide the needed scaffolding to develop and incorporate a systematic succession management and onboarding effort. The steps and guiding questions integrate knowledge from mid-career faculty research and practice (Baker \& Manning, in press) and are informed by knowledge of institutional structures in higher education.

\section{Action Steps for Talent Management}

Given the needs of mid-career faculty members and the institutions in which they are employed, we offer action steps and directed questions to guide succession management and onboarding development efforts.

1. Identify primary stakeholders who have a vested interest in the success of mid-career faculty (e.g., department chair, faculty representative, associate dean of faculty development, institutional advancement, admissions department).

Ask yourself this: Who or what units are most relevant to the success of mid-career faculty? And who or what is most affected by their efforts (e.g., their departmental peers, interdisciplinary campus partners, students, etc.)? In order to effectively support the long-term development of mid-career faculty, campus leaders and those tasked with career development must gain clarity about and agree on the role(s) and contribution(s) of formal (and informal) campus leaders at mid-career. Simply put, success in organizations depends on strategic partnerships. Succession management and onboarding programming should incorporate those key stakeholders throughout the process.

2. Determine content and content delivery methods (e.g., workshops, mentoring program) that are in hand and/or needed to ground 
succession management and onboarding efforts and who can deliver the needed content.

The academy is notorious for a one-day or weekend workshop to prepare future department chairs (Gmelch, 2002). However, such experiences as a standalone effort are grossly inadequate and merely serve as an orientation to campus leadership roles, at best. Succession management and onboarding requires a more sustained, ongoing effort that employs multiple long-term developmental opportunities delivered at the individual, team, and cohort levels. Online learning and resources, in-person workshops, peer-to-peer mentoring, leadership coaching, observation of veteran leaders, and external leadership development training should all be employed on an ongoing basis when developing and delivering career development programming. Later in this article, we offer some associated recommendations.

3. Determine how success is defined and how it is measured.

As noted earlier, succession management and onboarding are career development tools that, when appropriately planned and executed, support the achievement of individual and organizational outcomes. A systematic, comprehensive approach to mid-career faculty development includes the identification of key performance metrics and the associated development of assessment tools that measure success. Institutional leaders should be able to communicate in-depth the competencies needed to be successful in leadership roles and positions on campus and how success (individual and institutional) is defined, measured, and supported as connected to institutional imperatives and strategic priorities (Ndunguru, 2012). It is important to note, this step also aids current institutional leaders' identification of those mid-career faculty who have the potential, based on experience and competencies, to be successful in leadership roles enhanced with the right training and development. It is nearly impossible to identify 
the right talent unless skills, competencies, and metrics for success are clearly articulated.

\section{Critical Content Areas for Mid-Career Faculty Success}

Per the aforementioned Step 2, a critical step to building an effective succession management and onboarding effort is developing content areas that inform program delivery. In Table 1, we highlight three broad content areas, and the relevant stakeholders, in which mid-career faculty would benefit from more deliberate career development programming: a HI ED 101 course, leadership development, and attaining full professorship.

Table 1. Critical Content Areas and Stakeholders for Mid-Career Faculty

\begin{tabular}{|c|c|c|c|}
\hline & $\begin{array}{c}\text { Higher Education } \\
101\end{array}$ & $\begin{array}{c}\text { Leadership } \\
\text { development }\end{array}$ & $\begin{array}{l}\text { Attaining full } \\
\text { professorship }\end{array}$ \\
\hline Topics & $\begin{array}{l}\text { *Budgets } \\
\text { (department, } \\
\text { institution) } \\
\text { *Fundraising } \\
\text { *Admissions } \\
\text { (recruitment } \\
\text { strategy, org. } \\
\text { structure) } \\
\text { *Campus offices, } \\
\text { key contacts, } \\
\text { main charge }\end{array}$ & $\begin{array}{l}\text { *Mentoring vs. } \\
\text { coaching } \\
\text { *Mission and vision } \\
\text { setting } \\
\text { *Strategy and goal } \\
\text { setting } \\
\text { *Personnel } \\
\text { management } \\
\text { *Persuasion/ } \\
\text { developing your voice } \\
\text { *Effective } \\
\text { communication } \\
\text { *Effective delegation } \\
\text { *Time management } \\
\text { *Succession planning }\end{array}$ & $\begin{array}{l}\text { *Institutional } \\
\text { requirements/ } \\
\text { processes } \\
\text { *SWOT analysis } \\
\text { *Needs assessment } \\
\text { *Goal setting } \\
\text { *Cultivating a } \\
\text { mentoring network } \\
\text { *Need resources } \\
\text { *Personal development } \\
\text { plan }\end{array}$ \\
\hline $\begin{array}{l}\text { Key } \\
\text { stakeholders }\end{array}$ & $\begin{array}{l}\text { *Business office } \\
\text { *Institutional } \\
\text { advancement } \\
\text { *Admissions office } \\
\text { leadership } \\
\text { *Academic/student } \\
\text { affairs leadership }\end{array}$ & $\begin{array}{l}\text { *Subject matter } \\
\text { experts (SMEs) } \\
\text { *Provost/academic } \\
\text { dean } \\
\text { *Faculty developers } \\
\text { *Director, Center for } \\
\text { Teaching \& Learning } \\
\text { *Alumni with relevant } \\
\text { experience }\end{array}$ & $\begin{array}{l}\text { *Academic dean/dean } \\
\text { of faculty } \\
\text { *Faculty developer } \\
\text { *Director, Center for } \\
\text { Teaching \& Learning } \\
\text { * Successful divisional } \\
\text { peers } \\
\text { *Current and former } \\
\text { members of } \\
\text { personnel committee }\end{array}$ \\
\hline
\end{tabular}




\section{HI ED 101}

We propose the development of a course titled HI ED 101 as a content area to ensure mid-career faculty members have the needed knowledge about core higher education functional areas that are essential to the effective operation of institutions. Faculty members are trained in their disciplines, many of which do not include a focus on higher education institutions. A review of institutional and departmental budgets, funding sources, and types of funds, which factor into decision-making, for example, helps to provide the needed grounding to take informed actions. Additionally, knowledge about institutional advancement and how fundraising efforts and donor relations are cultivated can prove useful for current and aspiring institutional leaders.

Such a course, for example, could include a series of brown bag lunch sessions led by different campus stakeholders (e.g., vice president for institutional advancement, director of admissions) in which details about their unit or department are provided along with an introduction of relevant staff members and their roles. An understanding of how their unit or department supports the institutional mission and how mid-career faculty can better engage could be informative. The objective is to put knowledge in the hands of those who need it to ensure mid-career faculty members have a common language and knowledge base from which to build. Furthermore, such programming ought to be rooted in capacity building across disciplinary and institutional domains, which is paramount to overcoming the fragmented, decentralized structures that characterize the academy.

\section{Leadership Development}

Institutional efforts contribute to mid-career faculty vitality, or lack thereof, and previous research has shown that encouraging mid-career faculty to take on new roles fosters much needed vitality (Strage et al., 2008). In fact, researchers have revealed that mid-career faculty desire opportunities to develop leadership skills (Laursen \& Rocque, 2009). 
In order to lead effectively, one must have the skills and competencies to do so.

A focus on leadership development must foster critical skill development in areas such as mission and vision development, strategy and goal setting, and personnel management. Furthermore, mid-career is a pivotal career moment that requires one to develop effective mentoring skills to support early career colleagues while also finding oneself in need of mentoring support to continue to develop professionally and personally (Baldwin \& Chang, 2006; Miller et al., 2008). For example, a multi-series mentoring workshop could focus on how to be an effective mentor, including a framework on how to establish and communicate relationship expectations and mentor/mentee needs and offer advice on how to incorporate periodic assessments when serving as a mentor. A subsequent session could be focused on helping the mid-career faculty member engage in a needs assessment to identify areas of growth related to career advancement goals and associated skill development as well as advice on how to cultivate a network of mentors to support desired growth.

Given department chairs are familiar with what specific supports are needed for these faculty members, department chairs can be instrumental to leadership development efforts if they have been trained effectively (Creswell \& Brown, 1992; DeZure et al., 2014). This prior research, coupled with the understanding that mid-career faculty need to feel valued and that they are contributing to the growth of the institution, reiterates that it is advantageous to facilitate a systematic, comprehensive succession management and onboarding effort.

\section{Attaining Full Professorship}

The academic journey toward advancement is riddled with barriers, particularly for women and faculty of color on their path to full professorship (Baker, 2020). In turn, we propose onboarding content to help dissipate the detrimental impact of such barriers on mid-career faculty members' professional development and well-being. Widely reported obstacles 
include lack of clarity in the expectations for promotions, a feeling of stagnation in their careers, and a lack of resources, such as time (Buch et al., 2011; Gardner \& Blackstone, 2013; Karpiak, 1996; Petter et al., 2018).

To remedy these concerns, prior research has pointed to the importance of faculty being able to deepen their expertise in their field (Willis \& Tosti-Vasey, 1988) and having access to time as a resource, such as through the form of course releases or sabbaticals (Welch et al., 2019). Such practices are crucial to mid-career faculty members for fulfilling their responsibilities, yielding greater productivity, and gaining a competitive edge for promotions (Pastore, 2013; Pastore et al., 2019; Welch et al., 2019).

Sessions could be organized by division to facilitate a more targeted disciplinary perspective led by the dean of faculty along with the chair of the faculty personnel committee. Topic areas include an overview of institutional requirements for promotion, the process that informs decision-making, and lessons learned from those who already achieved full professor rank to diffuse the lack of clarity that accompanies this career transition (Baldwin \& Chang, 2006; Gardner \& Blackstone, 2013). Other sessions could be dedicated to faculty providing peer review and feedback of dossier materials, which would also be advantageous for expanding faculty members' professional networks.

\section{Conclusion}

The higher education landscape is evolving and diversifying. The academy is in need of effective leaders to manage the myriad challenges and opportunities, such as funding challenges, student access, and public mistrust of higher education (Pedris, 2018; White, 2016). We cannot expect faculty members to assume leadership positions and be successful in those roles without intentionally providing them a scaffold of support. Institutional leaders have an opportunity to rewrite the current leadership narrative from one of obligation and something to be avoided to one in which professional and personal development 
opportunities abound. Such a view helps shape a healthy, robust leadership pipeline and ensures that it is full of promising, well-prepared future leaders. Succession management and onboarding are wise investments and a good use of institutional resources given that the outcomes of not having such training, including ill-prepared, ineffective, disengaged institutional leaders, are more costly.

\section{Acknowledgments}

Thank you to Mary Dean Sorcinelli, Adam Grimm, and Aimee Terosky for their advice and feedback during the writing of this manuscript.

\section{Biographies}

Vicki L. Baker, MBA, MS, PhD, is a Professor of Economics and Management at Albion College. She is the co-author of over 70 articles and books exploring the faculty experience, career development, and liberal arts colleges. Her most recent book, Charting Your Path to Full: A Guide for Women Associate Professors (Rutgers University Press), was published in April 2020.

Caroline Manning, BS, is a recent graduate of Albion College, where she earned her degree in Psychological Sciences and served as Vicki Baker's research assistant. She is currently a doctoral student in the Industrial/Organizational Psychology Department at The Pennsylvania State University.

\section{References}

Amey, M. J. (2006). Leadership in higher education. Change, 38(6), 55-58. https://doi.org/10.3200/CHNG.38.6.55-58 
Austin, A. E. (2010). Supporting faculty members across their careers. In K. J. Gillespie \& D. L. Robertson (Eds.), A guide to faculty development (pp. 363-378). Jossey-Bass.

Austin, A. E., \& Sorcinelli, M. D. (2013). The future of faculty development: Where are we going? New Directions for Teaching and Learning, 2013(133), 85-97. https:/doi.org/10.1002/tl.20048

Baker, V. L. (2020). Charting your path to full: A guide for women associate professors. Rutgers University Press.

Baker, V. L., Lunsford, L. G., \& Pifer, M. J. (2015). Systems alignment for comprehensive faculty development in liberal arts colleges. To Improve the Academy, 34(1-2), 91-116. https://doi.org/10.1002/tia2.20029

Baker, V. L., Lunsford, L. G., \& Pifer, M. J. (2017). Developing faculty in liberal arts colleges: Aligning individual needs and organizational goals. Rutgers University Press.

Baker, V. L., Lunsford, L. G., \& Pifer, M. J. (2019). Patching up the "leaking leadership pipeline": Fostering mid-career faculty succession management. Research in Higher Education, 60(6), 823-843. https://doi. org/10.1007/s11162-018-9528-9

Baker, V. L., \& Manning, C. E. N. (in press). A mid-career faculty agenda: A review of four decades of research and practice. In L. W. Perna (Ed.), Higher education: Handbook of theory and research. Springer. https://doi. org/10.1007/978-3-030-43030-6_10-1

Baker, V. L., Pifer, M. J., \& Lunsford, L. G. (2018). Faculty development in liberal arts colleges: A look at divisional trends, preferences, and needs. Higher Education Research \& Development, 37(7), 1336-1351. https://doi.org/10 .1080/07294360.2018.1483901

Baker-Fletcher, K., Carr, D., Menn, E., \& Ramsay, N. J. (2005). Taking stock at mid-career: Challenges and opportunities for faculty. Teaching Theology and Religion, 8(1), 3-10. https://doi.org/10.1111/j.1467-9647.2005.00217.x

Baldwin, R. G. (1981). Expanding faculty options: Career development projects at colleges and universities. American Association for Higher Education.

Baldwin, R. G., \& Chang, D. A. (2006). Reinforcing our "keystone" faculty: Strategies to support faculty in the middle years of academic life. Liberal Education, 92(4), 28-35.

Belker, J. S. (1985). The education of mid-career professors: Is it continuing? College Teaching, 33(2), 68-71. https://doi.org/10.1080/87567555.1985.1 0532290

Bradt, G. B., \& Vonnegut, M. (2009). Onboarding: How to get your new employees up to speed in half the time. John Wiley \& Sons.

Buch, K., Huet, Y., Rorrer, A., \& Roberson, L. (2011). Removing the barriers to full professor: A mentoring program for associate professors. Change, 43(6), 38-45. https://doi.org/10.1080/00091383.2011.618081 
Chiocchio, F., \& Gharibpour, M. (2017). The neglected elements of implementing strategic succession management in public organizations. World Academy of Science, Engineering and Technology, International Journal of Economics and Management Engineering, 11(6), 1557-1560.

Clark, S. M., \& Corcoran, M. E. (1989). Faculty renewal and change. New Directions for Institutional Research, 1989(63), 19-32. https://doi.org/10. 1002/ir.37019896304

Creswell, J. W., \& Brown, M. L. (1992). How chairpersons enhance faculty research: A grounded theory study. The Review of Higher Education, 16(1), 41-62. https://doi.org/10.1353/rhe.1992.0002

Croom, N. N. (2017). Promotion beyond tenure: Unpacking racism and sexism in the experiences of Black womyn professors. The Review of Higher Education, 40(4), 557-583. https://doi.org/10.1353/rhe.2017.0022

Day, D. V. (2007). Developing leadership talent: A guide to succession planning and leadership development: Guidelines for effective talent management. The Society for Human Resource Management. https://www.shrm. org/hr-today/trends-and-forecasting/special-reports-and-expert-views/ Documents/Developing-Leadership-Talent.pdf

DeZure, D., Shaw, A., \& Rojewski, J. (2014). Cultivating the next generation of academic leaders: Implications for administrators and faculty. Change, 46(1), 6-12. https://doi.org/10.1080/00091383.2013.842102

Dye, D., Campbell, C., Hilliker, L., Anderson, E., Lapter, A., \& Jellerette, D. (2016). Succession management: Developing the next generation of federal leaders. Deloitte Development, LLC. https://www2.deloitte.com/ content/dam/Deloitte/us/Documents/public-sector/us-fed-successionmanagement.pdf

Eddy, P. L., \& Ward, K. (2015). Lean in or opt out: Career pathways of academic women. Change, 47(2), 6-13. https://doi.org/10.1080/00091383.2015.10 18082

Furniss, W. T. (1981). Reshaping faculty careers. Change, 13(7), 38-39.

Gardner, S. K., \& Blackstone, A. (2013). "Putting in your time": Faculty experiences in the process of promotion to professor. Innovative Higher Education, 38(5), 411-425. https://doi.org/10.1007/s10755-012-9252-x

Gmelch, W. H. (2002). The call for department leaders [Paper presentation]. Annual Meeting of the American Association of Colleges for Teacher Education, New York, NY, United States.

Groves, K. S. (2019). Examining the impact of succession management practices on organizational performance: A national study of US hospitals. Health Care Management Review, 44(4), 356-365. https://doi.org/10.1097/ HMR.0000000000000176

Hart, J. (2016). Dissecting a gendered organization: Implications for career trajectories for mid-career faculty women in STEM. The Journal of Higher 
Education, 87(5), 605-634. https://doi.org/10.1080/00221546.2016.1177 7416

Hirsch, A. S. (2017, August 10). Don't underestimate the importance of good onboarding. Society of Human Resource Management. https://www.shrm. org/resourcesandtools/hr-topics/talent-acquisition/pages/dont-underestimate-the-importance-of-effective-onboarding.aspx

June, A. W. (2017a, January 15). How to cultivate faculty leaders. The Chronicle of Higher Education. https://www.chronicle.com/package/how-tocultivate-faculty-leaders/

June, A. W. (2017b, January 15). What 4 colleges are doing to groom new leaders. The Chronicle of Higher Education. https://www.chronicle.com/ article/what-4-colleges-are-doing-to-groom-new-leaders/

Karpiak, I. E. (1996). Ghosts in a wilderness: Problems and priorities of faculty at mid-career and mid-life. The Canadian Journal of Higher Education, 26(3), 49-78. https://doi.org/10.47678/cjhe.v26i3.183244

Korn Ferry International. (2018). 4 things successful companies do amazingly well in onboarding their talent. Focus. https://focus.kornferry.com/ employee-engagement/4-things-successful-companies-do-amazinglywell-in-onboarding-their-talent/

Lamber, J., Ardizzone, T., Dworkin, T., Guskin, S., Olsen, D., Parnell, P., \& Thelen, D. (1993). A "community of scholars?": Conversations among midcareer faculty at a public research university. To Improve the Academy, 12(1), 13-26.

Laursen, S., \& Rocque, B. (2009). Faculty development for institutional change: Lessons from an advance project. Change, 41(2), 18-26. https://doi. org/10.3200/CHNG.41.2.18-26

Lunsford, L. G., Baker, V. L., \& Pifer, M. J. (2018). Faculty mentoring faculty: Career stages, relationship quality, and job satisfaction. International Journal of Mentoring and Coaching in Education, 7(2), 139-154. https://doi. org/10.1108/IJMCE-08-2017-0055

Mathews, K. (2018). Growing our own: Cultivating faculty leadership. Change, 50(3-4), 88-92. https://doi.org/10.1080/00091383.2018.1509617

Maurer, R. (2016, July 5). 5 steps to create an onboarding program for managers. Society of Human Resource Management (SHRM). https://www.shrm. org/ResourcesAndTools/hr-topics/talent-acquisition/pages/5-steps-create-onboarding-program-managers.aspx

Miller, R. L., Wadkins, T. A., \& Davis, S. F. (2008). Contrasting perspectives on mentoring new faculty. The Journal of Faculty Development, 22(2), 135-143.

Mirza, B. (2009, October 8). HR leaders rethink strategies during recession. HR News. https://www.shrm.org/hr-today/news/hr-news/pages/rethinkstrategies.aspx

To Improve the Academy • Vol. 40, No. 1 • Fall 2021 
Misra, J., Lundquist, J. H., Holmes, E., \& Agiomavritis, S. (2011). The ivory ceiling of service work. Academe, 97(1), 22-26.

Ndunguru, C. A. (2012, September 15). Executive onboarding: How to hit the ground running. The Public Manager, 41(3), 6-9. https://www.td.org/ magazines/the-public-manager/executive-onboarding-how-to-hit-theground-running

Nguyen, D. (2018, April 12). Four business benefits of good employee onboarding experiences. D!gitalist Magazine. https://www.digitalistmag. com/future-of-work/2018/04/12/4-business-benefits-good-employeeon-boarding-experience-can-provide-06031573

Norman, B. (2019). Faculty leadership and institutional resilience: Indicators, promising practices, and key questions. Change, 51(4), 48-54. https://doi. org/10.1080/00091383.2019.1618145

Olsen, D. (1992). Interviews with exiting faculty: Why do they leave? To Improve the Academy, 11(251), 35-47.

Pastore, D. L. (2013). Faculty perspectives on Baldwin and Chang's mid-career faculty development model. The Journal of Faculty Development, 27(2), 25-32.

Pastore, D. L., Dahlin, S., \& Morton, J. (2019). Mid-career faculty development model: Sport management faculty perspectives. The Physical Educator, 76(4), 1102-1127. https://doi.org/10.18666/TPE-2019-V76-14-8874

Pedris, L. (2018, March 27). To understand the rise of campus activism, listen to these students. The Aspen Institute. https://www.aspeninstitute.org/ blog-posts/understanding-rise-student-activism-college-campuses/

Petter, S., Richardson, S., \& Randolph, A. B. (2018). Stuck in the middle: Reflections from the AMCIS mid-career workshop. Communications of the Association for Information Systems, 42(1), 557-576.

Rockquemore, K. A., \& Ann, D. K. (2016). For a diverse faculty, start with retention. Inside Higher Ed. https://www.insidehighered.com/advice/2016/01/ 06/how-retain-diverse-faculty-essay

Romano, J. L., Hoesing, R., O’Donovan, K., \& Weinsheimer, J. (2004). Faculty at mid-career: A program to enhance teaching and learning. Innovative Higher Education, 29(1), 21-48. https://doi.org/10.1023/B:IHIE.0000035365. 92454.a5

Rothwell, W. J., Jackson, R. D., Ressler, C. L., Jones, M. C., \& Brower, M. (2015). Career planning and succession management: Developing your organization's talent-for today and tomorrow (2nd ed.). ABC-CLIO.

Snell, A. (2006). Researching onboarding best practice: Using research to connect onboarding processes with employee satisfaction. Strategic $H R$ Review, 5(6), 32-35. https://doi.org/10.1108/14754390680000925

Strage, A., \& Merdinger, J. (2015). Professional growth and renewal for midcareer faculty. The Journal of Faculty Development, 28(3), 41-50. 
Strage, A., Nelson, C., \& Meyers, S. (2008). "Stayin' alive": Meeting faculty mid-career professional renewal needs. Metropolitan Universities, 19(1), 71-83.

Templeton, L., \& O’Meara, K. (2018). Enhancing agency through leadership development programs for faculty. The Journal of Faculty Development, 32(1), 31-36.

Ward, K., \& Wolf-Wendel, L. (2012). Academic motherhood: How faculty manage work and family. Rutgers University Press.

Ward, K., \& Wolf-Wendel, L. (2016). Academic motherhood: Mid-career perspectives and the ideal worker norm. New Directions for Higher Education, 2016(176), 11-23. https://doi.org/10.1002/he.20206

Welch, A. G., Bolin, J., Reardon, D., \& Stenger, R. (2019). Mid-career faculty: Trends, barriers, and possibilities. Journal of the Professoriate, 10(1), 22-42.

White, J. S. (2016, March 23). Choosing to lead. Inside HigherEd. https://www. insidehighered.com/advice/2016/03/23/importance-exercising-leadershipevery-level-college-administration-essay

Willis, S. L., \& Tosti-Vasey, J. (1988, November). Professional competence in mid-career college faculty [Paper presentation]. Annual Meeting of the Gerontological Society, San Francisco, CA, United States. 